\title{
Cell Volume Regulation and Apoptotic Volume Decrease in Rat Distal Colon Superficial Enterocytes
}

\author{
Stefania Antico Maria Giulia Lionetto Maria Elena Giordano Roberto Caricato \\ Trifone Schettino
}

Dept. of Biological and Environmental Sciences and Technologies (DiSTeBA), University of Salento, Lecce, Italy

\section{Key Words}

Cell volume $\cdot$ Apoptosis $\cdot$ AVD $\cdot$ RVD $\cdot$ RVI $•$ Calcium activated potassium channel $\bullet$ Colon

\begin{abstract}
Background: The colon epithelium is physiologically exposed to osmotic stress, and the activation of cell volume regulation mechanisms is essential in colonocyte physiology. Moreover, colon is characterized by a high apoptotic rate of mature cells balancing the high division rate of stem cells. Aim: The aim of the present work was to investigate the main cell volume regulation mechanisms in rat colon surface colonocytes and their role in apoptosis. Methods: Cell volume changes were measured by light microscopy and video imaging on colon explants; apoptosis sign appearance was monitored by confocal microscopy on annexin V/propidium iodide labeled explants. Results: Superficial colonocytes showed a dynamic regulation of their cell volume during anisosmotic conditions with a Regulatory Volume Increase (RVI) response following hypertonic shrinkage and Regulatory Volume Decrease (RVD) response following hypotonic swelling. RVI was completely inhibited by bumetanide, while RVD was completely abolished by high $\mathrm{K}^{+}$or iberiotoxin treatment and by extracellular $\mathrm{Ca}^{2+}$ removal. DIDS incubation was also able to affect the RVD response. When colon explants were exposed to $\mathrm{H}_{2} \mathrm{O}_{2}$ as apoptotic inducer, colonocytes underwent an isotonic volume decrease ascribable to Apoptotic Volume Decrease (AVD) within about four hours of exposure. AVD was shown to precede annexin V positivity. It was also inhibited by high $\mathrm{K}^{+}$or iberiotoxin treatment. Interestingly, treatment with iberiotoxin significantly inhibited apoptosis progression. Conclusions: In rat superficial colonocytes $\mathrm{K}^{+}$efflux through high conductance $\mathrm{Ca}^{2+}$-activated $\mathrm{K}^{+}$channels (BK channels) was demonstrated to be the main mechanism of RVD and to plays also a crucial role in the AVD process and in the progression of apoptosis.
\end{abstract}




\section{Introduction}

The epithelium of the colon, as well as the epithelium of the entire gastrointestinal tract, is one of the most rapidly self-renewing tissues in the body, turning over 3-5 days. The high epithelial renewal is ensured by a coordinated series of proliferation, migration, differentiation and apoptosis processes. Stem cells residing within the base of the Lieberkühn crypts are responsible for continuously producing transit cells that undertake differentiation following a limited number of cellular divisions. The differentiated cells reach the surface of the colon, where they are then removed by apoptosis [1]. The high division rate of stem cells and the corresponding high apoptotic rate of mature cells ensure the high cellular turnover of the colon epithelium. Proliferative stem and precursor cells occupy the bottom two-thirds of crypts, whereas differentiated cells constitute the surface epithelium and top third of the crypts [1].

Apoptosis is, therefore, a fundamental process for the tissue homeostasis in the colon epithelium and any alterations of the normal apoptotic process can lead to pathological conditions such as the survival of a malignant clone in the case of adenocarcinoma [2] or the increased loss of epithelium in the case of ulcerative colitis [3]. While much is known about the cellular proliferation in the colon epithelium, much less is known about the cell loss by apoptosis.

One of the main and distinctive characteristics of apoptosis is represented by cell shrinkage. The apoptotic cell shrinkage occurs in two distinct stages: the first phase starting before cell fragmentation or formation of the apoptotic body and the second phase associated with cell fragmentation [4]. The early-phase shrinkage is termed Apoptotic Volume Decrease (AVD) [5] and corresponds to an isotonic shrinkage of the cell. Apoptotic cell shrinkage results from a net loss of $\mathrm{K}^{+}, \mathrm{Cl}^{-}$and organic osmolytes from the cell [5-14]. A throughout description of the volume and ion changes during the two stages of apoptotic shrinkage has been given in Ehrlich ascites tumour cells [15]. However, the causal relationship between ion loss, cell shrinkage and apoptosis is not completely understood. The shrinkage is seen early after apoptotic stimuli and seems to be a prerequisite for apoptosis $[5,7,10,15]$. In different cell models AVD has been demonstrated to occur before the activation of caspases, the release of cytochrome $\mathrm{c}$ from mitochondria and DNA fragmentation. The initial ion loss is found to be secondary to changes in plasma membrane permeability to cations and anions [10,16-18]. Recently, apoptotic cell shrinkage has been associated with alterations of cell volume regulation process [10] and changes in cell volume have been recognized as important signals in basic cellular physiological processes such as survival or death [19-21].

The cell volume regulation mechanisms are highly conserved and principally similar in cells from various tissues as well as between evolutionary distant species [22-27]. Following a hypotonic cell swelling, they consist in the release of osmolytes, mainly $\mathrm{K}^{+}$and $\mathrm{Cl}^{-}$, followed by loss of osmotically obliged water and are termed Regulatory Volume Decrease (RVD); following a hypertonic shrinkage they consist in the uptake of osmolytes followed by gain of osmotically obliged water and are termed Regulatory Volume Increase (RVI) [28, 27]. As regards the colon, its predominant physiological role is to regulate luminal fluid and electrolyte contents and in doing so it is physiologically exposed to osmotic stress. Increased osmolarity is generated during colonic water absorption and feces consolidation [29]. In fact, the most important contributing factor to hard feces formation is the osmotic pressure generated in the descending colon by a hypertonic absorbate in the intercryptal extracellular space and a hypotonic luminal content [30]. Also electrolyte and fluid secretion, which is essential for maintaining the overall fluidity of colonic luminal contents and also serves as a chief host defense mechanism [31], challenges cell volume constancy and has been associated to cell shrinkage in colon crypts. In addition, digestive disorders such as carbohydrates malabsorption increase intracolonic osmolarity by accumulation of undigested compounds and fermented products [32]. Most of the information concerning cell volume regulation mechanisms in colonocytes arises from studies carried out on crypt cells. Guinea pig crypt colonocytes were demonstrated to undergo RVI following carbachol induced cell shrinkage 
and the RVI response was dependent on the operation of the $\mathrm{Na}^{+}-\mathrm{K}^{+}-2 \mathrm{Cl}^{-}$contransporter [31]. Rat and mouse crypt colonocytes were demonstrated to undergo RVD following exposure to hypotonic stress [33, 34]. The regulatory response was inhibited by 5-nitro-2(3-phenylpropylamino)-benzoate (NPPB), a $\mathrm{Cl}^{-}$channel blocker, and by $\mathrm{Ba}^{2+}$, a $\mathrm{K}^{+}$channel blocker, and was dependent on the presence of external $\mathrm{Ca}^{2+}$ [33]. Weyard et al. [35] studied the effects of hypertonicity in rat colonic crypt cells and detected a decrease in the open probability of a $16 \mathrm{pS} \mathrm{K} \mathrm{K}^{+}$channels. In humans Lomax et al. [36] found two different subset of channels in colon crypts: an intermediate conductance (23-29 pS) $\mathrm{Ca}^{2+}$-dependent channel and a $138 \mathrm{pS}$ maxi $\mathrm{K}^{+}$channel. The authors suggested that the maxi $\mathrm{K}^{+}$channel may have a role in volume regulation. In addition, Sand et al. [37] also demonstrated the importance of intermediate conductance $\mathrm{K}^{+}$channel for regulatory volume changes. No information is available about RVD, RVI and AVD responses in superficial colonocytes which are the cell type mainly interested by the apoptotic process.

The aim of the present work was to study cell volume regulation mechanisms in superficial colonocytes of rat distal colon and to address their role in AVD focusing the attention on RVD mechanisms. The study was carried out on colon explants, which represent a tissue experimental model with intact tight junctions [38] retaining the original architecture of the tissue.

\section{Materials and Methods}

Male Wistar rats (70-100 g) were obtained from Harlan (Carezzana, Italy) and housed individually in animal cages at a temperature of $22 \pm 1^{\circ} \mathrm{C}$ with a $12: 12$ hour light-dark cycle and $30-40 \%$ humidity. The animals had ad libitum access to food and water. This study was carried out in strict accordance with the European Committee Council 106 Directive (86/609/EEC) and with the Italian animal welfare legislation (art 4 and 5 of D.L. 116/92).

All chemicals were reagent grade. Alexa Fluor $₫ 488$ annexin $V$ and propidium iodide were purchased from Life Technologies - Molecular Probes. All the other chemicals were purchased from Sigma (St. Louis, U.S.A.).

Stock solutions of iberiotoxin (100 $\mu \mathrm{M}$ in distilled water) and bumetanide $\left(10^{-2} \mathrm{M}\right.$ in DMSO) were prepared and kept at $-20^{\circ} \mathrm{C}$ until use. Unless otherwise noted solutions were freshly prepared.

Rats were sacrificed by cardiac arrest through the use of diethyl ether and the distal colon was removed by aseptic technique. The isolated colon was washed with sterile Hepes-Tris buffer solution containing (in $\mathrm{mM}$ ): $\mathrm{NaCl} 140, \mathrm{KCl} 5, \mathrm{MgCl}_{2} 1, \mathrm{CaCl}_{2} 2$, Hepes 10, glucose 10 adjusted to $\mathrm{pH} 7.4$ with Tris or Hepes. Then, the colon was opened longitudinally with surgical scissors and cut into explants of about $0.6 \mathrm{~cm}^{2}$ in size.

\section{Culture conditions}

Individual explants were washed with sterile Hepes-Tris buffer solution and placed in $60-\mathrm{mm}$ plastic tissue-culture dishes with the epithelium facing the gas-medium interface. Four ml of culture medium was added to each dish. The medium was DMEM (Dulbecco's Modified Eagle Medium) supplemented with glucose ( $5 \mathrm{mg}$ per $\mathrm{ml}$ ), tricine buffer ( $\mathrm{pH} 7.4 ; 10 \mathrm{mM})$, L-glutamine $(2 \mathrm{mM})$, hydrocortisone hemisuccinate $(0.5 \mu \mathrm{g}$ per $\mathrm{ml}$ ), $\beta$-retinyl acetate $(0.1 \mu \mathrm{g}$ per $\mathrm{ml}), 5 \%$ fetal bovine serum (FBS), penicillin G (100 U per ml), streptomycin (100 $\mu \mathrm{g}$ per $\mathrm{ml})$, gentamicin (50 $\mu \mathrm{g}$ per $\mathrm{ml})$, and amphotericin B $(0.25 \mu \mathrm{g}$ per $\mathrm{ml})$. The explants were incubated in an atmosphere of $95 \% \mathrm{O}_{2}$ and $5 \% \mathrm{CO}_{2}$ at $37{ }^{\circ} \mathrm{C}$. Cell viability was assessed by the Trypan blue exclusion test. The colon explants showed a viability of about $99 \%$ maintained for up to 14 days in culture. For all the experiments described in this study the explants were utilized within 24 hours from the isolation.

\section{Morphometric analysis of cell volume changes}

Cell volume changes were monitored by morphometric analysis of superficial colonocytes in freshly tissue fragments of colon explants observed by light microscopy. Briefly, a small tissue fragment (about 0.06 $\mathrm{cm}^{2}$ ) was dispensed on a poly-L-lysine coated slide. Then, a cover-slide was gently applied and the slide was immediately observed by an optic microscope (Eclipse E600, Nikon, Tokyo, Japan). The surface of the epithelium was focused. The images obtained from video camera (TK-C1381, JVC, Yokohama, Japan) were 
digitalised using the LUCIA ${ }^{\circledR}$ image analysis software (Nikon, Tokyo, Japan). The cell area of 2-D digitised colonocyte images were automatically calculated by the LUCIA imaging software. At least a minimum of 100 cells/field and 5 field per slide were analysed.

In the analysis of RVD and RVI responses, an isotonic Krebs solution (containing in mM: NaCl 124, $\mathrm{KH}_{2} \mathrm{PO}_{4} 1.25, \mathrm{MgCl}_{2} 1.8, \mathrm{KCl} 1.75, \mathrm{CaCl}_{2} 1.6, \mathrm{NaHCO}_{3} 26$ and glucose 10) was used. Hypotonic stress was performed by decreasing Krebs osmolarity from 290 to 160 mOsm by decrease of the NaCl concentration, whereas hypertonic stress was performed by increasing Krebs osmolarity from 290 to 365 m0sm by addition of $200 \mathrm{mM}$ sucrose. For both RVD and RVI experiments, adjacent fragments of the same explant were monitored in their cell volume changes before (control) and every $5 \mathrm{~min}$ for a total of about $35 \mathrm{~min}$ exposure to osmotic stress.

In the experiments with high $\left[\mathrm{K}^{+}\right], \mathrm{K}^{+}$was increased by 10 times (17.5 mM final concentration) by equimolar replacement of $\mathrm{Na}^{+}$. The tissue was incubated with high $\left[\mathrm{K}^{+}\right]$Krebs solution (containing in mM: $\mathrm{NaCl} 92.5, \mathrm{KH}_{2} \mathrm{PO}_{4} 1.25, \mathrm{MgCl}_{2} 1.8, \mathrm{KCl} 17.5, \mathrm{CaCl}_{2} 1.6, \mathrm{NaHCO}_{3} 26$ and glucose 10) and exposed to hypotonic stress.

For the AVD experiments $\mathrm{H}_{2} \mathrm{O}_{2}$ was added in the DMEM medium as proapototic agent [39] and the cell size was monitored (as reported above) after 2, 4, 6, 8 and 24 hours.

\section{Confocal microscopy detection of apoptosis}

One of the earliest indications of apoptosis is the translocation of the membrane phospholipid phosphatidylserine (PS) from the inner to the outer leaflet of the plasma membrane [40]. Once exposed to the extracellular environment, binding sites on PS become available for Annexin V, a $36 \mathrm{kDa}$, blood clotting factor that exhibits a high calcium-dependent specificity for PS binding [41]. Surface colonocytes were double marked with Alexa Fluor® 488 annexin $\mathrm{V}$ and propidium iodide which binds to nucleic acids, but can only penetrate the plasma membrane when membrane integrity is breached, as occurs in dying cells. Therefore, the combined use of the two markers allows the detection of appearance and progression of apoptosis.

Small fragments of colon explant were incubated with annexin $\mathrm{V}$ conjugated and propidium iodide solution (Alexa Fluor ${ }^{\circledR} 488$ annexin V diluted to 10\% in Hepes-Tris buffer solution containing $0.15 \mathrm{mM}$ propidium iodide) for $15 \mathrm{~min}$ in a humid chamber in the dark. After incubation, the tissue fragments was rapidly rinsed in Hepes-Tris buffer solution, mounted on a poly-L-lysine coated slide and finally viewed using a 100X NA plan apochromat objective mounted on a NIKON TE300 inverted microscope coupled to a NIKON C1 confocal laser scanning unit (Nikon, Tokyo, Japan). Alexa Fluor ${ }^{\circledR} 488$ annexin V and propidium iodide were excited using the Argon 488-nm and Elio-Neon 543-nm laser lines, respectively. Photomultiplier (PMT) and laser intensity settings and emission wavelengths were optimized for minimal bleed through between the two channels. In the tissue live cells, apoptotic and dead cells were distinguished on the basis of annexin $\mathrm{V}$ and propidium iodide positivity by setting different fluorescence threshold values for different regions of interest (ROIs). Unlabeled preparations were found to exhibit no fluorescence under the conditions used.

\section{Confocal immunofluorescence microscopy}

In order to define the precise localization of BK channels in rat distal colonic epithelium, colon explants were fixed in paraformaldehyde diluted to 2\% in Hepes-Tris solution from a stock solution of $20 \%$ paraformaldehyde in TBS containing (in $\mathrm{mM}$ ): $\mathrm{NaCl} 150$, Tris $10, \mathrm{MgCl}_{2} 1$, EGTA 1 adjusted to pH 7.4 with $\mathrm{NaOH}$, as previously described [26]. Sections of $10 \mu \mathrm{m}$ thickness were cut along planes perpendicular to the luminal epithelium surface through the use of a microtome (MICROM HM 500) and placed on poly-L-lysine coated glass slides. Sections were incubated with the monoclonal rabbit anti-BK ${ }_{\mathrm{Ca}}$ antibody (anti-KCNMA1) diluted 1:200 for 2 hours in a humid chamber, then washed three times with PBS (containing in $\mathrm{mM}: \mathrm{NaCl}$ 137, $\mathrm{KCl} 2.7, \mathrm{Na}_{2} \mathrm{HPO}_{4} 10, \mathrm{KH}_{2} \mathrm{PO}_{4} 1.76$ adjusted to $\mathrm{pH} 7.4$ with $\mathrm{NaOH}$ or $\mathrm{HCl}$ ) and finally incubated with the secondary antibody Alexa fluor 488 goat anti-rabbit IgG diluited 1:1000 for $30 \mathrm{~min}$ in a humid chamber in the dark. The slides were viewed using the $488 \mathrm{~nm}$ Argon laser line of a C1 NIKON confocal laser scanning unit coupled to a NIKON TE300 microscope with a 100X/1.30 oil objective (NIKON).

\section{Statistics}

Values are given as the mean \pm S.E. of the mean. Statistical tests utilized to evaluate statistical significance of differences were one Way ANOVA and Dunnett post test, two ways ANOVA and Bonferroni 


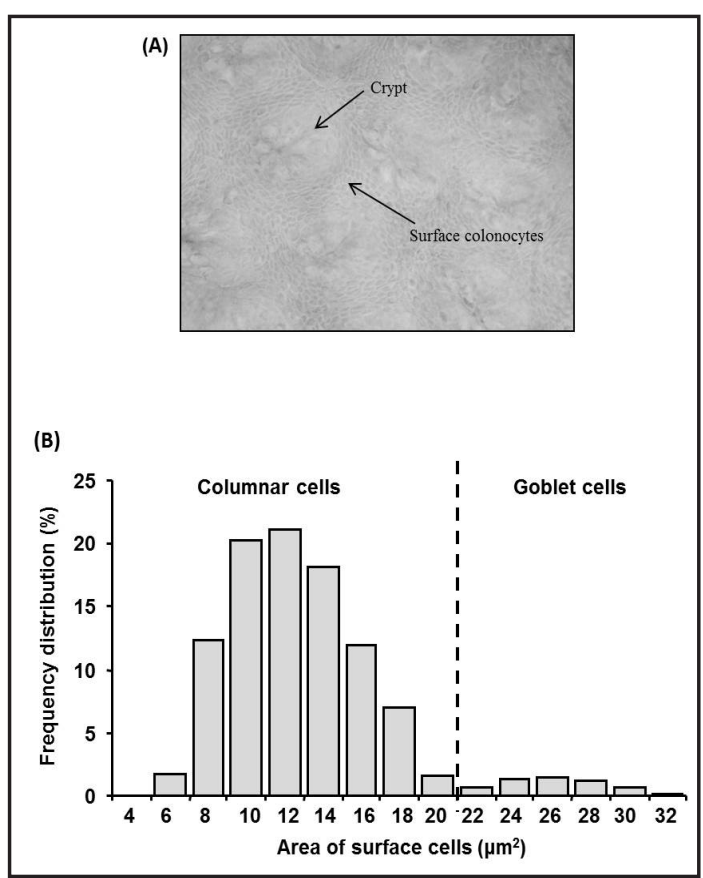

Fig. 1. $(A, B)$. (A) Representative optical image of rat colonic superficial epithelium (objective utilized: 40x). (B) Frequency distribution of superficial cell size quantified as the area of $2 \mathrm{D}$ digitized images (see Method section).

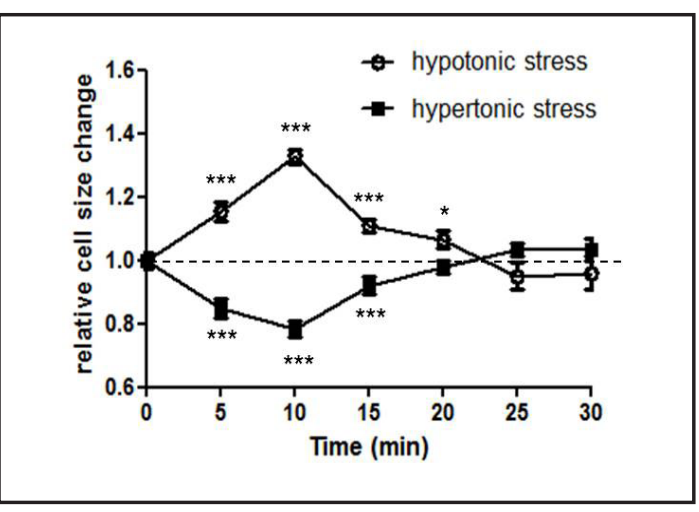

Fig. 2. Time-course of relative cell size changes in superficial colonocytes during exposure to hypertonic stress $(290 \rightarrow 365 \mathrm{mOsm})$ or hypotonic stress $(290 \rightarrow$ $160 \mathrm{mOsm}$ ) applied at time 0 . Cell size was quantified as the area of 2D digitized images of superficial colonocytes and espressed as relative changes vs time 0 . The dashed line across the time denotes the initial level of cell area. Data are expressed as mean \pm SEM of three independent experiments. For each experimental condition the statistical significance of data was analyzed by one-way ANOVA and Dunnet's multiple comparison tests (each value vs time 0 ). ${ }^{*}=$ $\mathrm{P}<0.05 ;{ }^{* * *}=\mathrm{P}<0.001$.

post test, as indicated in legends to figures. ${ }^{*}=\mathrm{P}<0.05 ;{ }^{* *}=\mathrm{P}<0.01,{ }^{* * *}=\mathrm{P}<0.001$. For the dose-response experiment of exposure to increasing concentration of $\mathrm{H}_{2} \mathrm{O}_{2}$ the Kruskall Wallis test was used to test the significance of the results.

\section{Results}

\section{RVD and RVI in surface colonocytes}

The appearance of the rat colon surface as observed by optical microscopy on freshly excised explants is reported in Fig. 1A. The crypt architecture is clearly visible with the colonocytes arranged around a central lumen. As reported in the Method section, cell size was quantified by measuring the area covered by single surface cells in 2-D digitised images. The morphometric analysis was performed on surface cells localized among the crypts. As reported in Fig. 2B the frequency distribution of cell size measured in superficial colonocytes showed a bimodal behavior, suggesting the presence of discrete populations on the basis of cell dimension: a most abundant population composed by smaller cells and a much less abundant one composed by larger cells. It is known the presence of different differentiate cell types in the colon surface [42]. Absorptive cells are the predominant epithelial cell type, followed by goblet cell, which are specialized for secretion of mucus. Occasionally, some enteroendocrine cells are present. Therefore, the first population is ascribable to enterocytes, while the second population is attributable to goblet cells, whose apical end is known to be occupied by a large mass of mucus. In the bimodal distribution the intersection of the two normal distributions (at about $20 \mu \mathrm{m}^{2}$ ) was used as the threshold for assigning cells to each population. All the present study focused on absorptive cells, therefore all data refers to cells whose area in 2D digitized image was below $20 \mu \mathrm{m}^{2}$.

First, we verify the presence of homeostatic mechanisms of cell volume regulation on colonic superficial enterocytes. To this end the epithelium was exposed to anisotonic conditions. 
When the explants were exposed to hypotonic stress, cell dimension initially increased for 5-10 min by about 30\% with respect to the initial value, because of the osmotic influx of water. Thereafter, it was observed a decrease of cell volume towards the initial value (Fig. 2), still persisting the stress. Instead, when the cells were exposed to hypertonic stress, they initially showed a cell volume decrease (by about $20 \%$ ), due to the osmotic efflux of water, followed by a recovery towards the initial value (Fig. 2). These findings demonstrate that rat superficial colonocytes show a dynamic regulation of their cell volume in anisosmotic conditions with a RVD response after hypotonic swelling and a RVI response after hypertonic shrinkage.

Ion transport mechanisms involved in RVD and RVI

With the aim of investigating the main ion transport mechanisms accounting for the RVI response in rat surface colonocytes, the explants were incubated with $10^{-5} \mu \mathrm{M}$ bumetanide (specific inhibitor of the $\mathrm{Na}^{+}-\mathrm{K}^{+}$$2 \mathrm{Cl}^{-}$cotransporter) before their exposure to hypertonic stress. As shown in Fig. 3 the RVI response following hypertonic cell shrinkage was completely inhibited. This result clearly demonstrates that in rat superficial colonocytes RVI is dependent on the $\mathrm{Na}^{+}-\mathrm{K}^{+}$$2 \mathrm{Cl}^{-}$cotransporter activity.

In order to investigate the main ionic mechanisms underlying RVD in rat surface colonocytes, the involvement of $\mathrm{K}^{+}$efflux was addressed by monitoring cell volume changes when the $\mathrm{K}^{+}$gradient across the cell membrane was neutralized. As reported in Fig. 4 (high $\mathrm{K}^{+}$trace), explants incubated in high- $\left[\mathrm{K}^{+}\right]$Krebs solution and exposed to hypotonic stress failed to show the characteristic hypotonic shrinkage that appears in control colonocytes. This result clearly demonstrated that the $\mathrm{K}^{+}$efflux represents one of the main ionic mechanisms that characterize RVD in these cells. Several types of $\mathrm{K}^{+}$channels have been identified in the surface cells of distal colon. Among them high conductance $\mathrm{Ca}^{2+}$ activated $\mathrm{K}^{+}$channel (BK channel) is the one for which localization and function is documented best [43]. Lomax et al. [36] suggested their involvement in cell

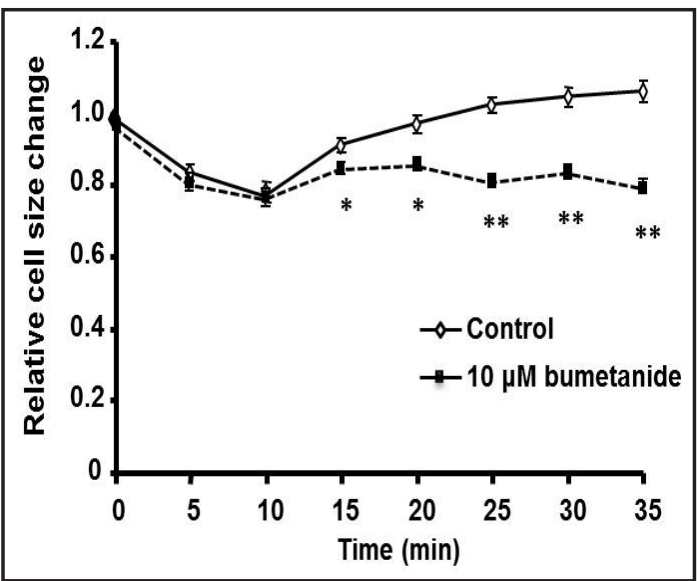

Fig. 3. Effect of $10 \mu \mathrm{M}$ bumetanide on RVI response in superficial colonocytes. The statistical significance of data was analyzed by two way ANOVA and Bonferroni post test. $*=\mathrm{P}<0.05$, $* *=\mathrm{P}<0.01$. Data are expressed as mean $\mathrm{SEM}$ of three independent experiments.

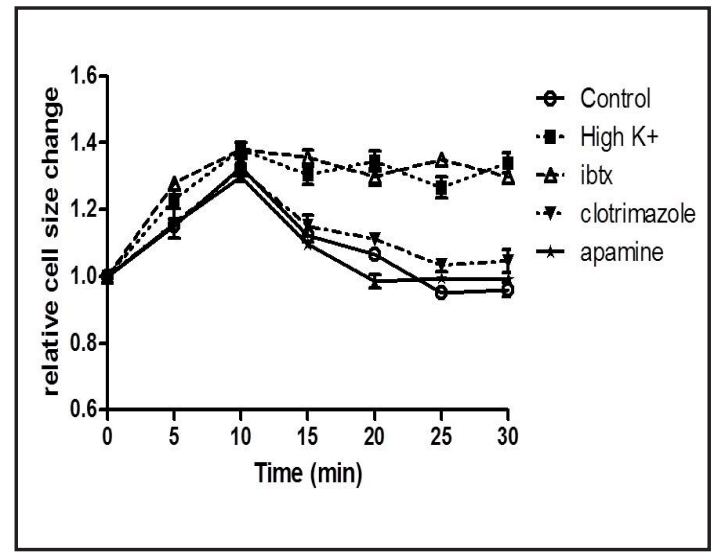

Fig. 4. Effect of high $\mathrm{K}^{+}, 0.1 \mu \mathrm{M}$ iberiotoxin (ibtx), $1 \mu \mathrm{M}$ chlotrimazole, and $1 \mu \mathrm{M}$ apamine on RVD response in superficial colonocytes. Data are expressed as mean \pm SEM of three independent experiments. For each experimental condition the statistical significance of data was analyzed by one-way ANOVA and Dunnet's multiple comparison tests (each value vs time 0). Dunnet test results: control trace: time $5,10,15$ vs time $0 \mathrm{P}<0.001$; time 20 vs time $0 \mathrm{P}<0.05$, time 25,30 vs time 0 not significant; high $\mathrm{K}^{+}$trace: each time $(5,10,15,20,25,30)$ vs time $0 \quad \mathrm{P}<0.001$; ibtx trace: each time $(5,10,15,20,25,30)$ vs time $0 \quad \mathrm{P}<0.001$; clotrimazole trace: time $5,10,15,20$ vs time $0 \mathrm{P}<0.001$; time 25,30 vs time 0 not significant; apamine trace: time $5,10,15$ vs time $0 \quad \mathrm{P}<0.001$; time $20,25,30$ vs time 0 not significant. 


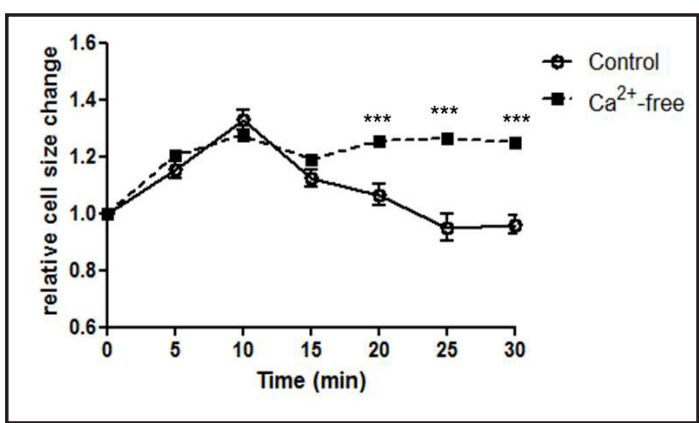

Fig. 5. Effect of extracellular $\mathrm{Ca}^{2+}$ removal on RVD response in superficial colonocytes. Data are expressed as mean \pm SEM of three independent experiments. The statistical significance of data was analyzed by two way ANOVA and Bonferroni post test. ${ }^{* * *}=\mathrm{P}<0.001$.

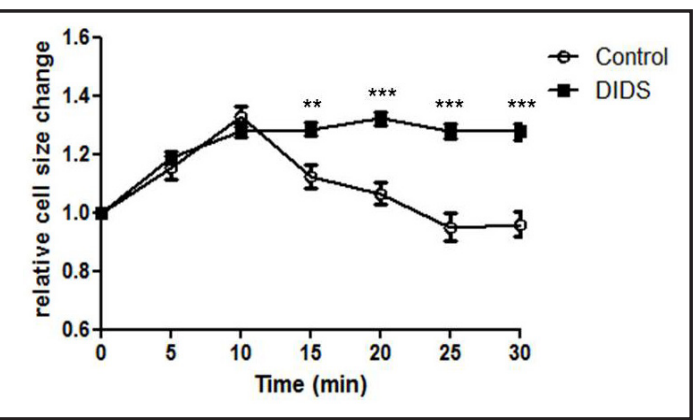

Fig. 6. Effect of $500 \mu \mathrm{M}$ DIDS on RVD response in superficial colonocytes. Data are expressed as mean \pm SEM of three independent experiments. For each experimental condition the statistical significance of data was analyzed by two way ANOVA and Bonferroni post test. ${ }^{* *}=\mathrm{P}<0.01 ; * * *=\mathrm{P}<0.001$.

volume homeostasis in human colonic crypts. When colon explants were preincubated with $0.1 \mu \mathrm{M}$ iberiotoxin (ibtx), a selective blocker of BK channels [44], before their exposure to hypotonic stress (Fig. 4), the initial swelling was not followed by the characteristic RVD response (Fig. 4, ibtx trace) as in the control. This result demonstrates that the activation of BK channels plays a pivotal role in the volume recovery mechanism after hypotonic swelling in the rat surface colonocytes. The involvement of other types of $\mathrm{Ca}^{2+}$ activated $\mathrm{K}^{+}$channels (intermediate conductance IK and small conductance SK) was ruled out by the use of $1 \mu \mathrm{M}$ clotrimazole (inhibitor of IK channels) [45], and $1 \mu \mathrm{M}$ apamine (inhibitor of SK channels) [46] (Fig. 4, apamine trace). In both these cases the initial swelling was followed by the RVD response as in the control.

As reported in Fig. 5, depletion of extracellular $\mathrm{Ca}^{2+}$ using $\mathrm{Ca}^{2+}$ free Krebs solution supplemented with $2 \mathrm{mM}$ EGTA completely abolished the RVD response to hypotonic stress indicating the $\mathrm{Ca}^{2+}$ dependence of the $\mathrm{BK}$ activation in superficial colonocytes,

Fig. 6 shows the confocal immunolocalization of BK channels on $10 \mu \mathrm{m}$ transversal section of rat distal colon cut along planes perpendicular to the luminal epithelium surface. Interestingly the expression of these channels appeared higher in superficial epithelium with respect to crypts. In the superficial cells the BK channels appeared expressed on both apical and basolateral membrane.

Effective volume regulation requires a parallel efflux of anions besides the efflux of $\mathrm{K}^{+}$. Therefore, the involvement of volume activated anion channel was tested by using $0.5 \mathrm{mM}$ DIDS as an inhibitor. As shown in Fig. 6, the drug was able to completely inhibit the RVD response following hypotonic stress in rat superficial colonocytes.

\section{Apoptotic Volume Decrease in rat distal colon explants}

After having demonstrated the presence of cell volume regulation mechanisms in superficial colonocytes and clarified the main underlying ion transport mechanisms, we investigated their role in the cell volume changes that characterize the apoptotic process. In particular the attention was focused on BK channels, which were shown to play a pivotal role in RVD. $\mathrm{H}_{2} \mathrm{O}_{2}$ was used as apoptotic inducer. It is known that $\mathrm{H}_{2} \mathrm{O}_{2}$ is able to induce apoptosis via the mitochondrial pathway involving the release of cytochrome $\mathrm{c}$ from mitochondria and activation of caspases 9 and 3 [39]. In addition, hydrogen peroxide $\left(\mathrm{H}_{2} \mathrm{O}_{2}\right)$ as apoptotic inducer in colonic epithelial cells is very important for the pathogenesis of inflammatory bowel disease [47]. In fact, in chronic inflammatory conditions like inflammatory bowel disease production of $\mathrm{H}_{2} \mathrm{O}_{2}$ by numerous stimulated phagocytes and from some bacteria species present in the gut is markedly increased $[48,49]$. This condition has been related to increased intestinal cell apoptosis leading to disruption of epithelial integrity. 
Fig. 7. $(A, B)$. BK localization in rat distal colon. The sections $(10 \mu \mathrm{m}$ trasverse section) were incubated with the monoclonal rabbit anti$\mathrm{BK}_{\mathrm{Ca}}$ antibody and Alexa fluor 488 goat anti-rabbit IgG (as secondary antobody) and visualized using confocal laser scanning microscopy as described (see Methods). (A) Rat distal colon trasverse section image observed at 20X objective; (B) Trasverse section of colon surphace epithelium colon epithelium observed at $100 \mathrm{X}$ objective.

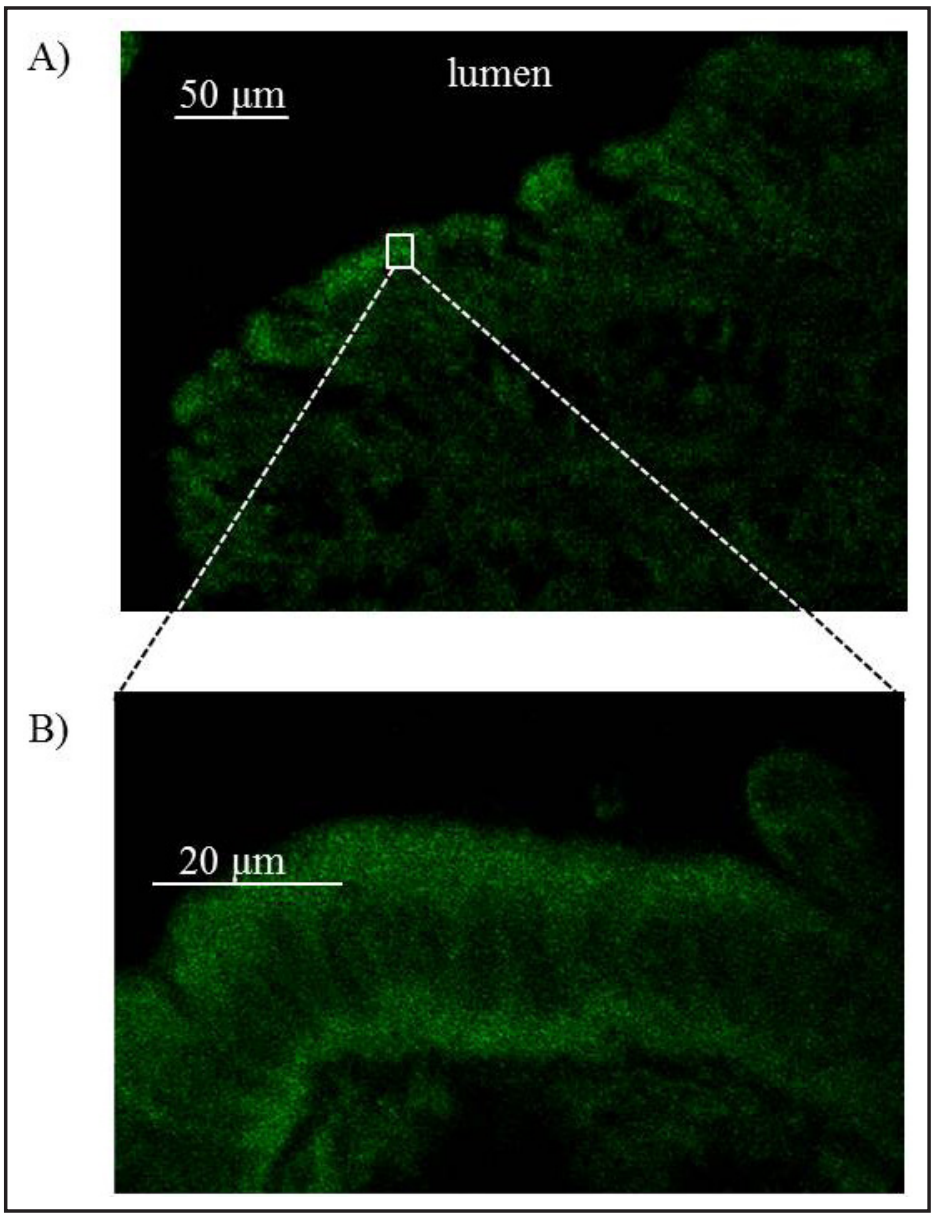

Fig. 8. Box plot of cell area of surface colonocytes following exposure to increasing concentration of $\mathrm{H}_{2} \mathrm{O}_{2}$ for $24 \mathrm{~h}$. The statistical significance of data was analyzed by Kruskal-Wallis test and Dunn's Multiple Comparison Test. The asteriscs indicate the statistical significance of the comparison between each concentration and control $\left(0 \mu \mathrm{M} \mathrm{H}_{2} \mathrm{O}_{2}\right)$.

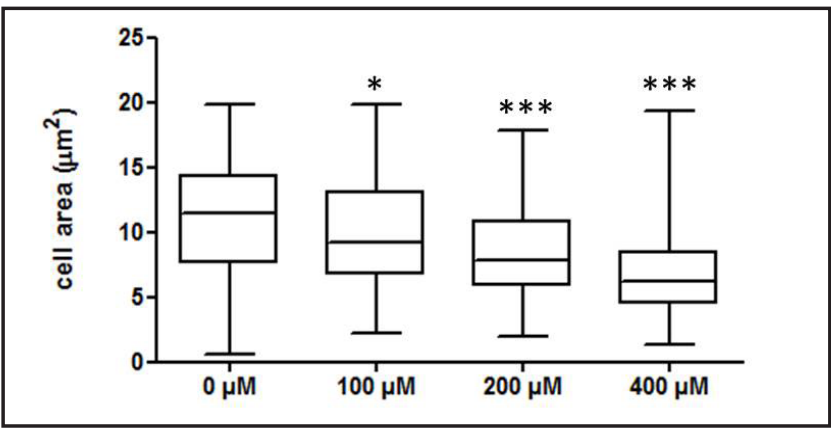

The explants were exposed to increasing concentration of $\mathrm{H}_{2} \mathrm{O}_{2}(100,200$ and 400 $\mu \mathrm{M}$ ) for $24 \mathrm{~h}$ and observed by optical microscopy for change of cell dimension (Fig. 8). The concentrations used and the prolonged exposure to $\mathrm{H}_{2} \mathrm{O}_{2}$ for 24 hours adopted are consistent with the $\mathrm{H}_{2} \mathrm{O}_{2}$ concentration that can be released by phagocytes and bacteria in chronic inflammatory conditions in the colon. In fact, as demonstrated in in vitro studies, macrophages and neutrophils are able to produce about $1 \mathrm{mM} \mathrm{H}_{2} \mathrm{O}_{2}$ in two hours [50] and some species of bacteria belonging to Streptococcus, Enterococcus and Lactobacillus genera residing on the mucus membranes are also able to produce comparable amounts of $\mathrm{H}_{2} \mathrm{O}_{2}$ in aerobic conditions [51]. The explant vitality (assessed by Trypan blue staining test) was about $99 \%$ for all the $\mathrm{H}_{2} \mathrm{O}_{2}$ concentration tested. The morphometric analysis of the surface cells reported in Fig. 9 revealed an isotonic shrinkage, which increased with increasing $\mathrm{H}_{2} \mathrm{O}_{2}$ concentration. $400 \mu \mathrm{M} \mathrm{H}_{2} \mathrm{O}_{2}$ was the concentration most effective at inducing a cellular shrinkage in the majority of surface cells, as indicated by the box plot graph. In fact at 400 $\mu \mathrm{M} \mathrm{H}_{2} \mathrm{O}_{2}$ the lowest median value and the lowest interquartile distance were observed. 
Fig. 9. $(A, B, C)$. (A) Timecourse of the area of $2 \mathrm{D}$ digitized images of superficial colonocytes in control condition or exposed to $400 \mu \mathrm{M} \mathrm{H}_{2} \mathrm{O}_{2}$. (B) Time-course of annexin $\mathrm{V}$ binding expressed as mean fluorescence intensity per field observed. The statistical significance of data was analyzed by two way ANOVA and Bonferroni post test. ${ }^{* *}=\mathrm{P}<0.01$; $^{* *}=\mathrm{P}<0.001$.

\section{Cell size}

(A)

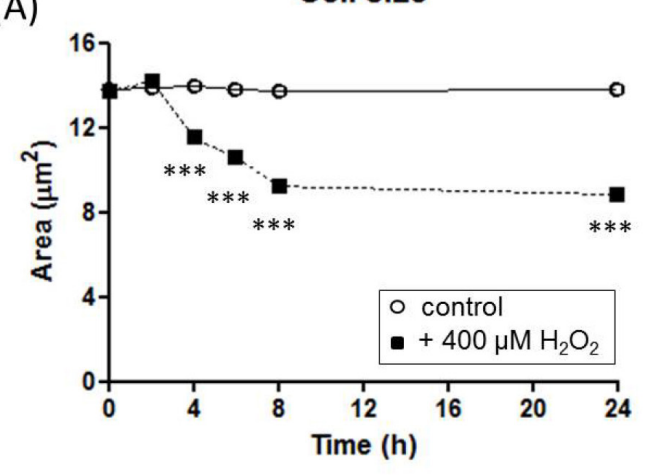

(B)

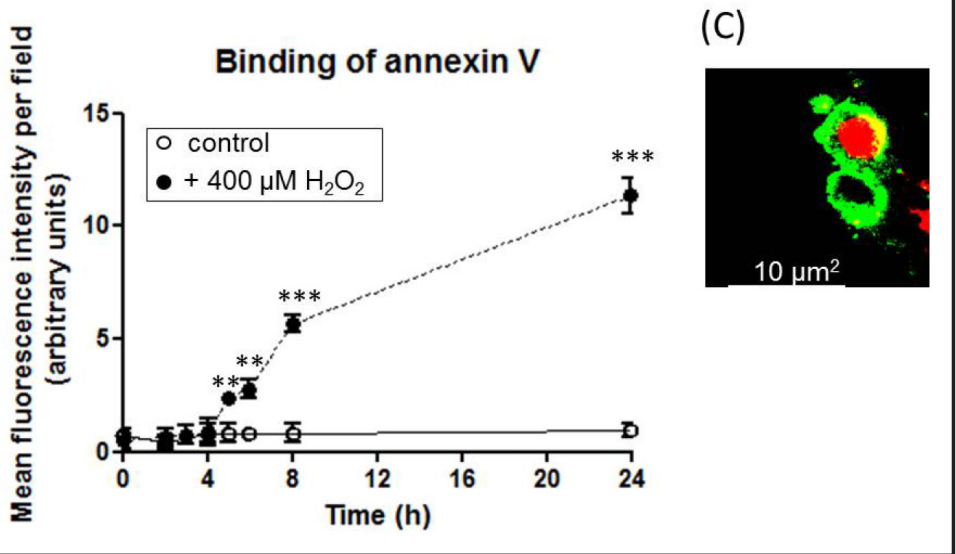

In order to characterize the observed isotonic shrinkage, the explants were then monitored over time for size change by morphometric analysis. As reported in Fig. 9A explants exposed to $\mathrm{H}_{2} \mathrm{O}_{2}$ showed a progressive isotonic cellular shrinkage, significantly detectable after 4 hours of exposure. In parallel the explants were monitored for possible appearance of apoptotic characteristic: they were double marked with Alexa Fluor® 488 annexin $\mathrm{V}$ and propidium iodide and observed by confocal microscopy (Fig. 9C). As shown in Fig. 9B annexin $V$ positivity, a characteristic apoptotic signal, was detectable following about 5 hours of treatment, then after to the isotonic shrinkage appearance.

This result clearly demonstrated that the observed isotonic cell volume decrease in superficial colonocytes can be ascribed to the Apoptotic Volume Decrease (AVD). It represents one of the first events of apoptosis and precedes the appearance of typical apoptotic characters such as phosphatidylserine translocation in the lipid bilayer, suggesting that AVD is one of the earliest events in the apoptotic program in rat surface colonocytes. The further decrease in the cell volume observed later could be ascribed to the cytoplasmic condensation due to blebbing of the plasma membrane and/or apoptotic body formation occurring later during the apoptosis.

\section{$B K$ channels in AVD response}

It is known that cell volume changes during AVD are the consequence of an exit of $\mathrm{Cl}^{-}$and $\mathrm{K}^{+}$from the cells (for a review see $[15,16,28]$ ). The involvement of $\mathrm{K}^{+}$efflux in superficial colonocytes was addressed by monitoring cell volume changes when the $\mathrm{K}^{+}$gradient across the cell membrane was neutralized. As reported in Fig. 10 (high potassium trace), explants incubated in high- $\left[\mathrm{K}^{+}\right]$physiological solution failed to show the characteristic isotonic shrinkage appearing in control explants. This result clearly demonstrated that $\mathrm{K}^{+}$efflux, as well as in RVD response, represents one of the main mechanisms underlying AVD in rat distal 


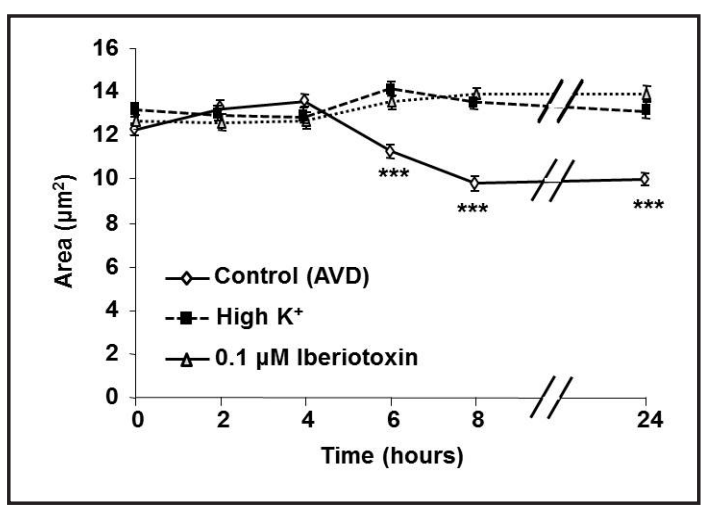

Fig. 10. Effect of high $\mathrm{K}^{+}$or $0.1 \mu \mathrm{M}$ iberiotoxin (ibtx) on AVD response in superficial colonocytes. Data are expressed as mean \pm SEM of three independent experiments. For each experimental condition the statistical significance of data was analyzed by oneway ANOVA and Dunnet's multiple comparison tests (each value vs time 0 ). ${ }^{* * *}=\mathrm{P}<0.001$.

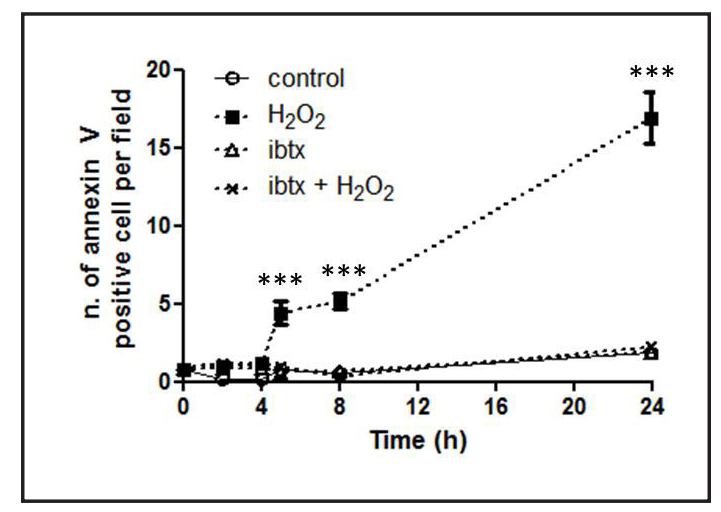

Fig. 11. Effect of the exposure to $0.1 \mu \mathrm{M}$ iberiotoxin on the progression of apoptosis. 4 experimental conditions were utilized: 1) control explants, 2) explants exposed to $400 \mu \mathrm{M} \mathrm{H}_{2} \mathrm{O}_{2}$,3) explants treated with $0.1 \mu \mathrm{M}$ iberiotoxin (ibtx), 4) explants pretreated with $0.1 \mu \mathrm{M}$ iberiotoxin and then exposed to 400 $\mu \mathrm{M} \mathrm{H}_{2} \mathrm{O}_{2}$. Data are reported as mean \pm SEM. The statistical significance of data was analysed by two way ANOVA and Bonferroni post test.*** $\mathrm{P}<0.001$.

colon surface enterocytes. In order to identify the specific potassium channels responsible for the $\mathrm{K}^{+}$efflux, the role of BK channels was addressed. Colon explants were preincubated with $0.1 \mu \mathrm{M}$ iberiotoxin and surface cells were monitored for their volume changes in control and after treatment with iberiotoxin. As reported in Fig. 10 (ibtx trace), iberiotoxin was able to completely abolish the characteristic isotonic shrinkage appearing later. This result clearly demonstrates the key role of BK channels in AVD.

\section{BK channels in the progression of apoptosis}

After having demonstrated that the BK channels blockade inhibits the AVD process, the possible relationship between $\mathrm{K}^{+}$efflux through $\mathrm{BK}$ channels and the progression of apoptosis was addressed by confocal microscopy on annexin $\mathrm{V}$ and propidium iodide double marked colon explants. Adjacent explants of the same distal colon were exposed to four different experimental conditions: 1) incubation with the culture medium DMEM for 24h (control); 2 ) exposure to $400 \mu \mathrm{M} \mathrm{H}_{2} \mathrm{O}_{2}$ for $24 \mathrm{~h} ; 3$ ) incubation with $0.1 \mu \mathrm{M}$ iberiotoxin; 4) preincubation with $0.1 \mu \mathrm{M}$ iberiotoxin and exposure to $400 \mathrm{\mu M} \mathrm{H}_{2} \mathrm{O}_{2}$ for $24 \mathrm{~h}$. 50 fields were observed at $100 \mathrm{X} \mathrm{per}$ condition and the number of annexin $\mathrm{V}$ positive cells per field is reported. A time-dependent increase in the number of annexin $\mathrm{V}$ positive cells was observed in the explants exposed to $\mathrm{H}_{2} \mathrm{O}_{2}$ (Fig. $11 \mathrm{~A}, \mathrm{~B}$ ) reaching the maximum value after $24 \mathrm{~h}$. This increase disappeared in the explants preincubated with $0.1 \mu \mathrm{M}$ iberiotoxin exposure and then exposed to $\mathrm{H}_{2} \mathrm{O}_{2}$. These data demonstrated that the inhibition of $\mathrm{K}^{+}$efflux through $\mathrm{BK}$ channels was able to inhibit the onset of apoptosis, whose an early signal is the phosphatidylserin translocation.

\section{Discussion}

Cell volume regulation is pivotal for epithelial cells which can experience osmotic stress and corresponding cell volume changes in several aspects of their functioning. Changes of extracellular osmolarity or variations of intracellular osmolarity, due to the entry or extrusion of osmotically active substances across the plasma membrane, represent continuous challenge to cell volume constancy (see [28] for a review). Recently, it has been recognised that alterations of cell volume participate in the machinery regulating cell proliferation and apoptotic cell death [52]. As suggested by Bortner and Cidlowski [53], it has become clear 
that cell volume regulation is an important component of life and death of a cell. In the present work the relationship between cell volume regulation and apoptosis was investigated in rat colon surface epithelium. Colon epithelium is physiologically challenged by osmotic stress during absorption or secretion of electrolytes and fluids. Moreover, it is characterized by a high cellular turnover ensured by a high division rate of stem cells localized in the crypts and a corresponding high apoptotic rate of mature cells at the luminal surface [1]. In the present work cell volume regulation mechanisms were characterized in superficial colonocytes of rat colon explants, and their involvement was addressed in the early phase of apoptosis. To our knowledge this is one of the few studies on cell volume regulation and its implication in apoptosis carried out in native epithelia, focusing on superficial colonocytes which are the cell type manly involved in the apoptotic process in the tissue homeostasis of the colon.

Surface colonocytes showed a dynamic regulation of their cell volume when exposed to osmotic stress. These cells are able to actively operate a RVI response after hypertonic shrinkage and a RVD response after a hypotonic swelling. RVI was dependent on $\mathrm{Na}^{+}-\mathrm{K}^{+}-2 \mathrm{Cl}^{-}$ cotransporter, as demonstrated by the completed inhibition of cell volume recovery after hypertonic shrinkage by bumetanide, specific inhibitor of the $\mathrm{Na}^{+}-\mathrm{K}^{+}-2 \mathrm{Cl}^{-}$. This result is in agreement with previous findings obtained on crypt guinea pig colonocytes where a $\mathrm{Na}^{+}-\mathrm{K}^{+}-$ $2 \mathrm{Cl}^{-}$dependent RVI response was observed following carbachol induced cell shrinkage [31] Therefore, the activation of $\mathrm{Na}^{+}-\mathrm{K}^{+}-2 \mathrm{Cl}^{-}$cotransport during RVI seems to be common to both crypts and surface epithelium in the colon.

On the other hand in rat superficial colonocytes RVD was dependent on the $\mathrm{K}^{+}$efflux through BK channels, as indicated by the completed inhibition of cell volume recovery following hypotonic swelling by high $\mathrm{K}^{+}$exposure or iberiotoxin treatment. The involvement of other types of $\mathrm{Ca}^{2+}$ activated $\mathrm{K}^{+}$channels in RVD was ruled out by the use of clotrimazole and apamine, which were ineffective on the RVD response. BK channels appeared expressed on both membranes by confocal immunofluorescence microscopy, as already found in rabbit colonic surface epithelium [54], eel intestine [26], and guinea pig distal colon [55]. Interestingly, they showed a major expression in superficial epithelium with respect to crypts, as previously observed in human colon [56]. This specific localization of BK channels on rat colon surface epithelium suggests that the activation of these channels could represent a specific volume regulation mechanism of differentiated colonocytes.

Previous works demonstrated intermediated conductance $\mathrm{Ca}^{2+}$ activated $\mathrm{K}^{+}$channels to be responsible for RVD in rat and human colon crypts respectively [37, 57]. Therefore, comparing the present data on superficial colonocytes with previous results on crypts it is possible to hypotize the contribution of different $\mathrm{K}^{+}$channels to cell volume regulation in the rat colon with a major contribution of BK in superficial epithelium and a major contribution of IK in crypts. In rat colon superficial cells RVD was dependent on the presence of external $\mathrm{Ca}^{2+}$. It is known that in some cell types BK are directly stretch activated but in the majority of cells the activation has been found to be secondary to an increase in $\left[\mathrm{Ca}^{2+}\right]_{\mathrm{i}}$. [58], Therefore, it is reasonable to assume that in superficial colonocytes a swelling activated influx of $\mathrm{Ca}^{2+}$ increases cytosolic $\mathrm{Ca}^{2+}$, thereby activating BK channels on plasma membrane.

Effective volume regulation requires a parallel efflux of anions across the plasma membrane besides the efflux of $\mathrm{K}^{+}$[27]. An osmotically induced $\mathrm{Cl}^{-}$conductance in a colonic epithelium has been already described for T84 cells using patch-clamp whole-cell recording [59] and in isolated crypts from the rat colon [57]. In superficial colonocyte RVD response was completely inhibited by the $\mathrm{Cl}^{-}$channel blocker DIDS, suggesting that the hypotonicity induced BK channel activation is paralleled by a $\mathrm{Cl}^{-}$channel activation in superficial colonocytes.

In the present work the characterization of cell volume regulation mechanisms in surface colonocytes and the finding of the pivotal role of BK channels were followed by the study of the involvement of these channels in apoptosis.

When rat colon explants were exposed to oxidative stress induced by treatment with $\mathrm{H}_{2} \mathrm{O}_{2}$, colonocytes underwent apoptosis within few hours from the application of the stress, as indicated by the increase in the binding to annexin V. A significant increase in the annexin 
$\mathrm{V}$ binding with respect to the basal value was observed after $5 \mathrm{~h}$ of exposure to $\mathrm{H}_{2} \mathrm{O}_{2}$. In parallel the cells were monitored for possible changes in their cell size. Superficial colonoyets showed a multistep decrease of their volume during $24 \mathrm{~h}$ of observation. After 4 hours from the application of the oxidative stress the cells showed a first decrease of cell volume, which can be ascribed to AVD, one of the earliest events in the apoptotic program. In rat colon surface cells, as previously observed in eel intestine [14], AVD was shown to precede a key hallmark of apoptosis (occurring after 5 hours of exposure to the oxidative stress) such as externalization of membrane phosphatidylserine. Thereafter, the cells showed a further cell volume reduction that can be attributed to the cytoplasmic condensation due to blebbing of the plasma membrane and apoptotic body formation occurring later during the apoptotic process.

During apoptosis the cell shrinkage occurs in the absence of extracellular osmotic challenge, suggesting that AVD is activated independently of changes in the extracellular osmotic environment. Although AVD occurs under isotonic conditions, several authors have suggested that the loss of cell volume during apoptosis may share some of the ionic mechanisms that participate in basal volume homeostasis, thus linking AVD to RVD $[5,14]$. Several authors have suggested that as in RVD, AVD arises from an exit of $\mathrm{Cl}^{-}$and $\mathrm{K}^{+}$from the cells (for a review see $[15,16,28]$ ). The importance of cation channels has been widely demonstrated [60] and various $\mathrm{K}^{+}$channels appear to be involved in AVD, depending on the cell type or stimulus used [53].

Particularly, with respect to the molecular identity of the $\mathrm{K}^{+}$channel involved in both AVD and RVD, it is still uncertain if the $\mathrm{K}^{+}$currents in AVD and RVD are driven by the same type of channels. For example, Elliott and Higgins [13] suggested that in T lymphocytes the same $\mathrm{IK}_{\mathrm{Ca}}$ channel is involved in both RVD and AVD. Lionetto et al. [14] demonstrated in eel enterocytes that BK channels, which are involved in RVD in these cells, plays also a crucial role in the AVD process.

When rat colon explants were incubated with high $\mathrm{K}^{+}$saline solution, AVD was completely prevented. The same result was obtained with iberiotoxin incubation, strongly suggesting that $\mathrm{K}^{+}$efflux through BK channels, which are fundamental for RVD in superficial colonocytes, plays also a key role in the AVD process. Therefore, the same type of $\mathrm{K}^{+}$channels responsible for cell volume regulation is also used by the cells for the AVD process. Interestingly, the progression of apoptosis appeared inhibited after treatment with iberiotoxin, as indicated by ibtx inhibition of the annexin $\mathrm{V}$ positive cells appearance during the treatment of the tissue with $\mathrm{H}_{2} \mathrm{O}_{2}$. These results suggest that the activation of BK channels is a fundamental step in the apoptosis process in rat superficial colonocytes.

Although the signal transduction mechanisms underlying AVD activation in rat colonocytes need to be explored, it is possible to hypotize that signalling pathways responsible for AVD and RVD could share common downstream signals in BK channel activation. In turn, BK channel activation could represent a key event in the complex mechanisms of cell volume regulation and cell death in rat mature colonocytes.

In conclusion the present study demonstrated the direct involvement of cell volume regulation mechanisms in the induction of the AVD in rat colon superficial cells, pointing out that BK channel activation could represent a key event in the complex mechanisms of cell volume regulation and cell survival in these cells. This is of particular relevance for a tissue like the colon where cell volume regulation and apoptosis represent fundamental process of the cellular physiology. Due to the importance of apoptosis in the physiology and pathology of the colon, understanding of the early mechanisms of apoptosis can provide advanced clinical implications in cell therapy research.

\section{Acknowledgements}

This study was supported by MIUR. 


\section{References}

1 Reya T, Clevers H: Wnt signaling in stem cells and cancer. Nature 2005;34:843-850.

2 Yamamoto T, Igarashi N, Kato Y, Kobayashi M, Kawakami M: Apoptosis in adenocarcinoma and early adenocarcinoma in the colon. Histol Histopathol 1998;13:743-749.

- Goretsky T, Dirisina R, Sinh P, Mittal N, Managlia E, Williams DB, Posca D, Ryu H, Katzman RB, Barrett TA: p53 Mediates TNF-Induced Epithelial Cell Apoptosis in IBD. Am J Pathol 2012;181:1306-1315.

4 Benson RSP, Heer S, Dive C, Watson AJM: Characterization of cell volume loss in CEM-C7A cells during dexamethasone-induced apoptosis. Am J Physiol 1996;270:C1190-1203.

-5 Maeno E, Ishizaki Y, Kanaseki T, Hazama A, Okada Y: Normotonic cell shrinkage because of disordered volume regulation is an early prerequisite to apoptosis. Proc Natl Acad Sci USA 2000;97:9487-9492.

6 Best L, Sheader EA, Brown PD: A volume-activated anion conductance in insulin-secreting cells. Pflugers Arch 1996;431:363-370.

7 Bortner CD, Hughes FM Jr, Cidlowski JA: A primary role for $\mathrm{K}^{+}$and $\mathrm{Na}^{+}$efflux in the activation of apoptosis. J Biol Chem 1997;272:32436-32442.

8 Lang F, Madlung J, Uhlemann AC, Risler T, Gulbins E: Cellular taurine release triggered by stimulation of the Fas (CD95) receptor in Jurkat lymphocytes. Pflugers Arch 1998;436:377-383.

-9 Moran J, Hernandez-Pech X, Merchant-Larios H, Pasantes-Morales H: Release of taurine in apoptotic cerebellar granule neurons in culture. Pflugers Arch 2000;439:271-277.

10 Okada Y, Maeno E, Shimizu T, Dezaki K, Wang J, Morishima S: Receptor-mediated control of regulatory volume decrease (RVD) and apoptotic volume decrease (AVD). J Physiol 2001;532:3-16.

-11 Lang F, Lang KS, Wieder T, Myssina S, Birka C, Lang PA, Kaiser S, Kempe D, Duranton C, Huber SM: Cation channels, cell volume and the death of an erythrocyte. Pflugers Arch 2003;447:121-125.

-12 Bock J, Szabo I, Jekle A, Gulbins E: Actinomycin D-induced apoptosis involves the potassium channel Kv1.3. Biochem Biophys Res Commun 2002;295:526-531.

-13 Elliott JI, Higgins CF: IKCa1 activity is required for cell shrinkage, phosphatidylserine translocation and death in T lymphocyte apoptosis. EMBO 2003;4:189-194.

14 Lionetto MG, Giordano ME, Calisi A, Caricato R, Hoffmann EK, Schettino T: Role of BK channels in the Apoptotic Volume Decrease in native eel intestinal cells. Cell Physiol Biochem 2010;25:733-744.

$\checkmark 15$ Poulsen KA, Andersen EC, Hansen CF, Klausen TK, Hougaard C, Lambert IH, Hoffmann EK: Deregulation of apoptotic volume decrease and ionic movements in multidrug-resistant tumor cells: role of chloride channels. Am J Physiol 2010;298:C14-C25.

16 Okada Y, Maeno E: Apoptosis, cell volume regulation and volume-regulatory chloride channels. Comp Biochem Physiol A 2001;130:377-383.

17 Okada Y, Maeno E, Shimizu T, Manabe K, Mori S, Nabekura T: Dual roles of plasmalemmal chloride channels in induction of cell death. Pflugers Arch 2004;448:287-295.

18 Lang F, Foller M, Lang K, Lang P, Ritter M, Vereninov A, Szabo I, Huber SM, Gulbins E: Cell volume regulatory ion channels in cell proliferation and cell death. Methods Enzymol 2007;428: 209-225.

19 Lang F, Busch GL, Ritter M, Völkl H, Waldegger S, Gulbins E, Häussinger D: Functional significance of cell volume regulatory mechanisms. Physiol Rev 1998;78:247-306.

20 Lang F, Lepple-Wienhues A, Szabó I, Siemen D, Gulbins E: Cell volume in cell proliferation and apoptotic cell death; in Lang F (ed): Cell Volume Regulation. Basel, Karger, 1998, pp 158-168.

-21 Lang F, Ritter M, Gamper N, Huber S, Fillon S, Tanneur V, Lepple-Wienhues A, Szabó I, Gulbins E: Cell volume in the regulation of cell proliferation and apoptotic cell death. Cell Physiol Biochem 2000;10:417428.

22 Lang F, Busch GL, Volkl H: The Diversity of Volume Regulatory Mechanisms. Cell Physiol Biochem 1998;8:145.

23 Lionetto MG, Giordano ME, Nicolardi G, Schettino T: Hypertonicity stimulates $\mathrm{Cl}^{-}$transport in the intestine of freshwater acclimated eel, Anguilla anguilla. Cell Physiol Biochem 2001;11:41-54.

24 Lionetto MG, Giordano ME, De Nuccio F, Nicolardi G, Hoffman EK, Schettino T: Hypotonicity induced $\mathrm{K}^{+}$and anion conductive pathways activation in eel intestinal epithelium. J Exp Biol 2005;208:749-760.

25 Lionetto MG, Schettino $\mathrm{T}$ : The $\mathrm{Na}^{+}-\mathrm{K}^{+}-2 \mathrm{Cl}^{-}$cotransporter and the osmotic stress response in a model salt transport epithelium. Acta Physiol, 2006;187:115-124. 
Antico et al.: Cell Volume Regulation and AVD in Superficial Colonocytes

26 Lionetto MG, Rizzello A, Giordano ME, Maffia M, De Nuccio F, Nicolardi G, Hoffman EK, Schettino T: Molecular and functional expression of high conductance $\mathrm{Ca}^{2+}$ activated $\mathrm{K}^{+}$channels in the eel intestinal epithelium. Cell Physiol Biochem 2008;21:361-337.

27 Hoffmann EK, Lambert IH, Pedersen SF: Physiology of cell volume regulation in vertebrates. Physiol Rev 2009;89:193-277.

28 Hoffmann EK, Dunham PB: Membrane mechanisms and intracellular signalling in cell volume regulation. Int Rev Cytol 1995;161:173-262.

-29 29.Thiagarajah JR, Jayaraman S, Naftalin RJ, Verkman AS: In vivo fluorescence measurement of $\mathrm{Na}^{+}$ concentration in the pericryptal space of mouse descending colon. Am J Physiol 2001;281:C1898-C1903.

-30 Naftalin RJ: The dehydrating function of the descending colon in relationship to crypt function. Physiol Res 1994;43:65-73.

-31 Manabe K, Shimizu T, Morishima S, Okada Y: Regulatory volume increase after secretory volume decrease in colonic epithelial cells under muscarinic stimulation. Pflügers Arch 2004;448:596-604.

32 La JH, Feng B, Schwartz ES, Brumovsky PR, Gebhart GF: Luminal hypertonicity and acidity modulate colorectal afferents and induce persistent visceral hypersensitivity. Am J Physiol 2012;303:G802-G809.

-33 Diener M, Scharrer E: Swelling-activated conductances for chloride, potassium and amino acids in the rat colon: a whole-cell study. Exp Physiol 1995;80:411-428.

34 Mignen O, Le Gall C, Harvey BJ, Thomas S: Volume regulation following hypotonic shock in isolated crypts of mouse distal colon. J Physiol 1999;515:501-510.

-35 Weyand B, Warth R, Bleich M, Kerstan D, Nitschke R, Greger R: Hypertonic cell shrinkage reduces the $\mathrm{K}^{+}$ conductance of rat colonic crypts. Pflügers Arch 1998;436:227-232.

-36 Lomax RB, Warhurst G, Sandle GI: Characteristics of two basolateral potassium channel populations in human colonic crypts. Gut 1996;38:243-247.

-37 Sand P, Anger A, Ridqvist B: Hypotonic stress activates an intermediate conductance $\mathrm{K}^{+}$channel in human colonic crypt cells. Acta Physiol 2004;182:361-368.

38 Bjorkman DJ, Allan CH, Hagen SJ, Trier JS: Structural Features of Absorptive Cell and Microvillus Membrane Preparations From Rat Small Intestine. Gastroenterology 1986;91:1401-1414.

-39 Singh M, Sharma H, Singh N: Hydrogen peroxide induces apoptosis in HeLa cells through mitochondrial pathway. Mitocondrion 2007;7:367-373.

40 van Engeland M, Kuijpers HJH, Ramaekers FCS, Reutelingsperger CPM, Schutte B: Plasma membrane alterations and cytoskeletal changes in apoptosis. Exp Cell Res 1997;235:421-30.

41 van Engeland M, Nieland LJW, Ramaekers FCS, Schutte B, Reutelingsperger CPM: Annexin V-affinity assay: a review on an apoptosis detection system based on phosphatidylserine exposure. Cytometry 1998;31:1-9.

42 Colony PC: Structural characterization of colonic cell types and correlation with specific functions. Dig Dis Sci 1996;41:88-104.

43 Heitzmann D, Warth R: Physiology and pathophysiology of potassium channels in gastrointestinal epithelia. Physiol Rev 2008;88:1119-1182.

-44 Kaczorowski GJ, Knaus HG, Leonard RJ, Mcmanus OB, Garcia ML: High conductance calcium-activated potassium channels; structure, pharmacology, and function. J Bioenerg Biomembr 1996;28:255-267.

-45 Wulff H, Gutman GA, Cahalan MD, Chandy KG: Delineation of the clotrimazole/TRAM-34 binding site on the intermediate conductance calcium-activated potassium channel, IKCa1. J Biol Chem 2001;276:3204032045.

46 Castle NA, Haylett DG, Jenkinson DH:. Toxins in the characterization of potassium channels. Trends Neurosci 1989;12:59-65.

47 Uchiyama K, Naito Y, Takagi T, Mizushima K, Hayashi N, Handa O, Ishikawa T, Yagi N, Kokura S, Yoshikawa T: FGF19 Protects Colonic Epithelial Cells against Hydrogen Peroxide. Digestion 2011;83:180-183.

48 Nathan C: Points of control in inflammations. Nature 2002;420:846-852.

-49 Strus M, Gosiewski T, Fyderek K, Wedrychowicz A, Kowalska-Duplaga K, Kochan P, Adamski P, Heczko PB: A role of hydrogen peroxide producing commensal bacteria present in colon of adolescents with inflammatory bowel desease in perpetuation of the inflammatory process. J Physiol Pharmacol 2009;60:49-54.

-50 Becker S, Soukup JM, Gallagher JE: Differential particulate air pollution induced oxidant stress in human granulocytes, monocytes and alveolar macrophages. Toxicol In Vitro 2002;16:209-218. 
-51 Ocaña VS, Pesce de Ruiz Hogado AA, Nader Macías ME: Selection of vaginal $\mathrm{H}_{2} \mathrm{O}_{2}$-generating Lactobacillus species for probiotic use. Curr Microbiol 1999;38:279-284.

-52 Lang F: Mechanisms and Significance of Cell Volume Regulation. J Am Coll Nutr 2007;26:6135-6235.

-53 Bortner CD, Cidlowski JA: A necessary role for cell shrinkage in apoptosis. Biochem Pharmacol 1998;56:1549-1559.

54 Hay-Schmidt A, Grunnet M, Abrahamse SL, Knaus HG, Klaerke DA: Localization of Ca ${ }^{2+}$-activated bigconductance K+ channels in rabbit distal colon. Pflugers Arch 2003;446:61-68.

55 Zhang J, Halm ST, Halm DR: Role of the BK channel (KCa1.1) during activation of electrogenic $\mathrm{K}^{+}$secretion in guinea pig distal colon. Am J Physiol 2012; 303:G1322-G1334.

56 Sandle GI, Perry M, Mathialah T, Linley JE, Robinson P, Hunter M, MacLennan KA: Altered cryptal expression of luminal potassium (BK) channels in ulcerative colitis. J Pathol 2007;212:66-73.

57 Diener M, Nobles M, Rummel W: Activation of basolateral $\mathrm{Cl}^{-}$channels in the rat colonic epithelium during regulatory volume decrease. Pflugers Arch 1992;421:530-538.

-58 Weskamp M, Seidl W, Grissmer S: Characterization of the increase in $\left[\mathrm{Ca}^{2+}\right]_{\mathrm{i}}$ during hypotonic shock and the involvement of $\mathrm{Ca}^{2+}$-activated $\mathrm{K}^{+}$channels in the regulatory volume decrease in human osteoblast-like cells. J Membr Biol 2000;178:11-20.

59 Worrell RT, Butt AG, Cliff WH, Frizzell RA: A volume-sensitive chloride conductance in human colonic cell line T84. Am J Physiol 1989;256:C1111-C1119.

60 Karki P, Seong C, Kim JE, Hur K, Shin SY, Lee JS, Cho B, Park IS: Intracellular K+ inhibits apoptosis by suppressing the Apaf-1 apoptosome formation and subsequent downstream pathways but not cytochrome c release. Cell Death Differ 2007;14:2068-2075. 